\title{
„NIE STARCZY UST DO WYMÓWIENIA PRZELOTNYCH IMION TWOICH, WODO” - NAZWY WŁASNE W TWÓRCZOŚCI WISŁAWY SZYMBORSKIEJ
}

Słowa tematyczne: onomastyka literacka, nazwy własne w poezji, Wisława Szymborska

Wydawać by się mogło, że niemal dekadę po śmierci Wisławy Szymborskiej o jej wierszach powiedziano już wszystko - że jest to poezja i łatwa, i trudna w odbiorze, precyzyjna i wieloaspektowa, poruszająca się w obrębie potocznej polszczyzny i po mistrzowsku operująca słowem, ironiczna, dowcipna, sentymentalna; mówiąca o codzienności i jednocześnie intelektualnie odkrywcza; intymna i uniwersalna zarazem, powściągliwa i staroświecko „rozgadana”, dotykająca najistotniejszych spraw (nie tylko) ludzkiej egzystencji... Czy jest tu miejsce na kolejne egzegezy ${ }^{1}$ i nowe interpretacje? We wstępnej części studium poświęconego twórczości Szymborskiej Stanisław Balbus pisze:

Tkwi w tym wiele tajemnic poetyckiego warsztatu [...]. Są one [...] do rozwikłania, a w każdym razie do opisania przez badacza literatury, znawcę retoryki, stylistyki i tradycji form literackich. Tyle że rozwikłanie tego rodzaju zagadek literackich badaczowi [...] się nie opłaca. Cóż z tego bowiem, że niebywale finezyjne konstrukcje artystyczne badacz ów rozłoży na czynniki pierwsze, że nazwie je po swojemu [...], skoro przy takich zabiegach — ukazujących niewątpliwie i jasno [...] tkankę wiersza — natychmiast ulatnia się z tego wiersza poezja [...] (Balbus, 1996, s. 8).

1 „Dlaczego Szymborska? - pyta I. Gralewicz-Wolny. - Takie pytanie zadaje się chyba każdemu, kto chce dziś poświęcić tej poetce przynajmniej kilka stron tekstu, a co dopiero całą książkę. Co gorsza, bywa, że pytaniu temu towarzyszy nuta sarkazmu, która zdaje się podawać W wątpliwość zasadność zajmowania się twórczością tak często i tak dogłębnie komentowaną. W tle czai się posądzenie o pójście na łatwiznę, sugestia dokonania nieoryginalnego wyboru szerokiej, wygodnej ścieżki wytyczonej już wcześniej przez polonistyczne autorytety" (Gralewicz-Wolny, 2014, s. 9). 
Nie inaczej bywa w przypadku interpretacji językoznawczych, np. onomastycznych $^{2}$ - chcąc nie chcąc ich autorzy, skupiając się na starannym opisie poetyckich onomastykonów, tworzą często drobiazgowe katalogi nazw, poszukują ich etymologii, śledzą pozajęzykowe odesłania i rejestrują lingwistyczne gry, w których nazwy te uczestniczą. I niekiedy tracą to, co kryje się w analizowanych wierszach, co jest niewyrażalne, zamaskowane, przemilczane. Pamiętając o groźbie utraty tego, co poetyckie, warto zauważyć, że poddane obserwacji nazwy własne nieoczekiwanie sprawiają, że tekst rozkwita znaczeniami i multiplikuje własną postać. Zwrócenie uwagi na poetycką onimię jest tym istotniejsze, że bez trudu zauważymy jej znaczącą nieobecność w literaturoznawczej refleksji nad twórczością Wisławy Szymborskiej. Jak zauważyła Anna Pajdzińska — nazwy własne, szczególnie antroponimy, stanowią istotny składnik poetyckiego leksykonu Noblistki (Pajdzińska, 2010). Z perspektywy metodologicznej rozpoznania badaczki należy traktować jako pierwszy, indykatywny etap postępowania badawczego. Cóż bowiem z tego, że czytelnik rozpozna nazwę, sprawdzi w encyklopedii (w dzisiejszych czasach zapewne internetowej) jej denotat lub kryjącą się za nią historię, jeśli to i tak nie ustanowi pełnego (lub choćby potencjalnego) znaczenia tekstu? Z drugiej (literaturoznawczej) strony — czy wynikający z poetyckiego zdania sens jest pełen, jeśli nie widzi się tworzących je nazw własnych? Jeśli są one niemal przezroczyste? W obu przypadkach umyka nam, czytelnikom-badaczom, ,,radość uczestniczenia w intelektualnej grze zaproponowanej przez autorkę, radość smakowania subtelnych tonów tej poezji, wywikłanych ze sprzeczności, lęków, zwątpień i przekory" (Borkowska, 1991, s. 45). Prześledźmy — dla przykładu — odczytania „Portretu kobiecego” — wiersza, który zainteresował obie przywołane badaczki:

\footnotetext{
Musi być do wyboru.

Zmieniać się, żeby tylko nic się nie zmieniło.

To łatwe, niemożliwe, trudne, warte próby.

Oczy ma, jeśli trzeba, raz modre, raz szare, czarne, wesołe, bez powodu pełne łez.

Śpi z nim jak pierwsza z brzegu, jedyna na świecie.

Urodzi mu czworo dzieci, żadnych dzieci, jedno.

Naiwna, ale najlepiej doradzi.

Słaba, ale udźwignie.

Nie ma głowy na karku, to będzie ją miała.

Czyta Jaspersa i pisma kobiece.

Nie wie po co ta śrubka i zbuduje most [...].
}

${ }^{2}$ Dorobek onomastyki literackiej w tym zakresie został omówiony w artykule M. Graf i P. Grafa (2018, s. 15-21). 
Od razu trzeba zauważyć, że w literaturoznawczych interpretacjach twórczości W. Szymborskiej wskazuje się, że jest to obraz kobiety, jednak wnikliwe oko językoznawcy dostrzeże obecny w tytule przymiotnik. Zatem — być może — nie portret kobiety, ale tworzony kobiecym piórem. Subiektywny. Intymny. W pewnym sensie feministyczny. W opisie obrazów kobiecości dominują appellativa, co można interpretować w perspektywie funkcji uniwersalizującej. Tym bardziej więc zaskakuje jedyna w tym wierszu nazwa własna - Jaspers. Co można o niej powiedzieć?

Przede wszystkim można jej nie dostrzec, jak w przypadku szkicu Bożeny Karwowskiej (2004, s. 88), która zwraca uwagę na antynomiczne zestawienia leksemów odzwierciedlające złożoność kobiecej natury. Dla dostrzegającej ten antroponim Grażyny Borkowskiej istotą użycia nazwy własnej jest jej uniwersalność i encyklopedyzm, stąd pisząc o warsztacie poetyckim Szymborskiej badaczka notuje:

Jej wizerunek ,innej” kobiety daleki jest od arystokratyzmu i nadmiernej konsekwencji. O swojej bohaterce powie: „Czyta Jaspersa i pisma kobiece” [...]. Zdanie to można odnieść do samej Szymborskiej, autorki recenzji zamieszczanych w „Życiu Literackim”. Pisała tam poetka o wielkich dziełach i skromnych wydawnictwach przeznaczonych dla zwykłego czytelnika, takich jak poradniki, atlasy i książki kucharskie (Borkowska, 1991, s. 57).

W tym spojrzeniu nazwa zatraca swą wartość denotacyjną, stając się przypadkowym dość sygnałem odniesień (auto)biograficznych. Tymczasem Anna Pajdzińska zauważa:

Nawet jednak tak proste konstrukcje wymagają pewnej wiedzy o tym, co oznaczają nazwy własne. Konieczna jest świadomość, że są to antroponimy, lecz także wiedza o obszarze aktywności twórczej ludzi tak nazywanych. Jak na przykład ten, kto nie wie, że Jaspers był filozofem, zrozumie pośrednią charakterystykę kobiety? (Pajdzińska, 2010, s. 310).

W obu odczytaniach antroponim funkcjonuje jako proprialny ekwiwalent leksemu filozof/filozofowie, w pierwszej interpretacji stając się synonimem sztuki wysokiej, w drugiej natomiast... — tu trudno o interpretację — autorka wskazuje jednak, że miano filozofa jest nośnikiem charakterystyki pośredniej. Tymczasem warto zastanowić się, dlaczego właśnie Jaspers, a nie Kant, Hegel, Nietzsche, Schopenhauer, Husserl, Heidegger? Wszak zastosowanie onimu, nawet pozornie błahego czy przypadkowego, otwiera utwór na wiele dodatkowych dróg interpretacyjnych zależnych od tego, który aspekt działalności niemieckiego filozofa zainteresuje odbiorcę. Czy będzie to trop najoczywistszy - Karl Jaspers jako egzystencjalista, autor m.in. „Filozofii egzystencji”, dla którego w życiu człowieka istotną rolę odgrywają sytuacje graniczne, zmuszające go do podejmowania 
wysiłku przeobrażania siebie? Czy Jaspers psychoterapeuta, autor „Psychopatologii ogólnej” („Allgemeine Psychopathologie”), uznawanej za jedną z ważniejszych rozpraw w historii psychiatrii (Żelazny, 2010, s. 119)? A może Jaspers powojenny? Filozof, dla którego ważnym problemem stało się pojęcie winy. „Czy po Auschwitz da się jeszcze filozofować?" — pytała Justyna Jezierska (2018, s. 90) w artykule poświęconym temu okresowi działalności filozofa, zwracając m.in. uwagę na jego rozpoznania dotyczące winy zbiorowej $\mathrm{i}$ indywidualnej ${ }^{3}$. Poetycką odpowiedzią na to pytanie wydaje się wiersz „Jeszcze”, w którym, choć pojawiają się antroponimy (imię Natan, imię Dawida, Lech itd.), to nie pełnią one funkcji indywidualizującej, lecz generalizującą, sygnalizującą narodowość wiezionych na zagładę ludzi. W kontekście filozofii Jaspersa najważniejszy wydaje się tu wers pierwszy:

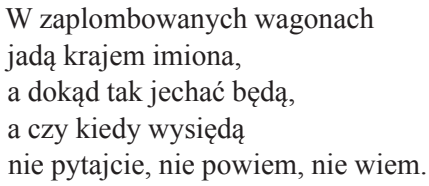

Spośród tych przykładowych, możliwych tropów interpretacyjnych warto skierować uwagę ku pierwszemu rozpoznaniu — ma ono bowiem istotny wpływ nie tylko na interpretację samego onimu, ale i na odkrycie realizowanego w wierszu poetyckiego konceptu. W tym wymiarze unikalna nazwa własna może wyznaczyć strategię odbiorczą tekstu. Ujmując zatem w największym skrócie rozpoznania niemieckiego egzystencjalisty, warto wskazać podkreślaną przez niego zmienność ludzkiej natury, dokonującą się zarówno pod wpływem indywidualnego doświadczenia, jak i ze względu na funkcjonowanie w określonej, temporalnej rzeczywistości. Egzystencjalna wolność człowieka polega m.in. na akceptowaniu sytuacji, w której się znalazł oraz przyjęciu określonej postawy wobec ograniczeń czasu i przestrzeni. Dokonujące się pod wpływem sytuacji graniczny $\mathrm{ch}^{4}$ zmiany nie mają jednostkowego charakteru, stanowią bowiem nieprzerwany proces. Ewolucję tę widać — moim zdaniem — w wierszu Szymborskiej, a szczególnie ważkie jest w tym kontekście zdanie: „Według Jaspersa człowiek

${ }^{3}$ J. Jezierska podaje: „Na ulicach niemieckich miast w 1945 r. wojska alianckie rozwieszały plakaty ze zdjęciami ofiar z obozów koncentracyjnych podpisane: «Diese Schandtaten: eure Schuld!» («Te haniebne czyny: wasza wina!»). K. Jaspers niedługo potem napisze: «Zdanie 'To wasza wina' oznacza jednak dziś znacznie więcej niż winę za wojnę. O plakacie tym już zapomniano. Ale nasze ówczesne doświadczenia mimo to trwają». Uważa on ponadto, że nieprzemyślany czy — jak powiedzieliby psychologowie - nieprzepracowany problem winy będzie rodził wiele negatywnych konsekwencji: na poziomie społecznym, instytucjonalnym, małych społeczności i indywidualnym" (Jezierska, 2018, s. 91). Ten aspekt filozofii Jaspersa może stanowić kontekst interpretacyjny innych utworów Szymborskiej, np. „Obóz głodowy pod Jasłem” czy „Jeszcze”.

${ }^{4}$ Sytuacja graniczna to jedno z kluczowych pojęć w filozofii Jaspersa (Kolasa, 2010). 
jest zawsze czymś więcej niż tym, co o sobie wie" (Sztobryn-Bochomulska, 2016, s. 150). Stąd liczne antynomie i paradoksy, szczególnie zestawione w kontrastowe pary, np. „Śpi z nim jak pierwsza z brzegu, jedyna na świecie”, wskazujące na niepełność naszego poznania. W podobny sposób można odczytać i inne wiersze poetki, np. „Cebulę” czy „Życie na poczekaniu”.

W szerszym kontekście wskazaną za Jaspersem ewolucję można utożsamić ze zmiennością, chwilowością, ulotnością obecnymi w innych utworach poetki. $\mathrm{Z}$ trudnym do zatrzymania upływem czasu i naszym do niego stosunkiem. Jak zauważa G. Borkowska:

\footnotetext{
Tym, co przynajmniej na pierwszy rzut oka decyduje o oryginalności poezji Szymborskiej, jest specyficzne usytuowanie podmiotu lirycznego. Głos poetki często zadziwia i zaskakuje, ponieważ dochodzi z miejsc nieprzewidzianych — z kąta sali, zza kulis, z muzealnej gabloty, z rynsztoków wielkiego miasta, z wnętrza snu, z głębokiej wody. Poezja Szymborskiej to skromna glosa na marginesie wielkiej księgi świata, szósty akt dramatu, rewers malarskiego obrazu (Borkowska, 1991, s. 54).
}

Konkluzję tę można uzupełnić, dopowiadając, że poetka stara się obserwować (i nazywać) świat, który jest w ciągłym ruchu. Jej strategia polega na dostrzeganiu najmniejszych detali rzeczywistości, drobiazgów, które pozwalałyby uchwycić moment, chwilę, stan pośredni pomiędzy formami materii. Patrzy z dystansu, gdyż to pozwala przyjąć określoną, często ironiczną perspektywę. „Przyszłość — któż ją odgadnie. / Przeszłości pewien — któż” zastanawia się Szymborska, pomijając jednak w tym pytaniu teraźniejszość, która - właśnie przez swą momentalność - ma umowny charakter („Czarna piosenka”). Przygląda się temu, co na peryferiach, a więc jeszcze lub już (nie)istotne, zepchnięte z głównego nurtu lub aspirujące do tego, by stać się ważne. Taką ambiwalencję postrzegania oddaje warstwa leksykalna poezji Szymborskiej i stosowana przez nią drobiazgowość opisu. Poetycki świat Noblistki wypełniają więc nie tylko ludzie, ale i przedmioty, zwłaszcza codziennego użytku, często te zagubione lub porzucone, niegdyś użyteczne, a dziś zbędne: „Zamiast powrotu wspomnień / w czasie umierania / zamawiam sobie powrót / pogubionych rzeczy” (,Martwa natura z balonikiem”). Stąd szczególne nagromadzenie onimów (np. w wierszu „Głosy”), ale też ich zaskakujący brak (np. „Martwa natura z balonikiem”), bowiem takimi ,zagubionymi” elementami rzeczywistości mogą też być nazwy własne. Zatem pozorne przemilczenie/pominięcie nazwy może być efektem podjętej przez poetkę próby jej „odnalezienia”. Widać to choćby w wierszu „Nic dwa razy”:

[...] Wczoraj, kiedy twoje imię

ktoś wymówił przy mnie głośno, tak mi było, jakby róża

przez otwarte wpadła okno. 
Dziś, kiedy jesteśmy razem,

odwróciłam twarz ku ścianie.

Róża? Jak wygląda róża?

Czy to kwiat? A może kamień? [...]

Wymówione przez kogoś imię, choć ważne, nie zostało zapisane — to było wczoraj, gdy samo jego brzmienie wzbudzało pozytywne emocje. Dziś jednak imię jest już nieistotne, ponieważ odeszło w zapomnienie uczucie, które się z nim wiązało. Co zatem pozwoli przywołać nazwę? Wydaje się, że poetka znalazła rozwiązanie — jest nim zatrzymanie czasu przypominające moment uchwycony na fotograficznej kliszy. Możemy w tym miejscu odwołać się do ustaleń Viléma Flussera, który pisze:

\footnotetext{
Sprowadzony do minimum zamiar fotografa to: po pierwsze, zakodować w obrazach swoje wyobrażenie o świecie. Po drugie, posłużyć się przy tym aparatem. Po trzecie, powstałe tak obrazy pokazać innym, aby mogły one posłużyć jako modele dla ich przeżyć, poznania, wartości i działań. Po czwarte, uczynić te modele możliwie najtrwalszymi. Krótko mówiąc: zamiarem fotografa jest informowanie innych i poprzez swoje fotografie uwiecznianie się w ich pamięci (Flusser, 2015, s. 90-91).
}

Idąc tropem rozpoznań Flussera, dopowiedzmy, że Szymborska — niczym fotograf — „zaszyfrowuje swoje pojęcia w obrazy” — zadaniem czytelnika/krytyka jest te pojęcia odszyfrować. „Właściwie każdy wiersz / mógłby mieć tytuł Chwila”, a „Czas przebiegł jak posłaniec z pilną wiadomością” — pisze poetka. Zatrzymanie obrazu świata (lub wyobrażenia o świecie) pozwala dokładniej się mu przyjrzeć, daje też czas na przywołanie związanych z nim nazw, jak w wierszu „Z nieodbytej wyprawy w Himalaje”:
Aha, więc to są Himalaje.
Góry w biegu na księżyc.
Chwila startu utrwalona
na rozprutym nagle niebie.

czy w „Znieruchomieniu”:
Miss Duncan, tancerka,
$[\ldots]$
Kiedy tak stoi w atelier fotograficznym,
z ruchu, z muzyki — ciężko, cieleśnie wyjęta,
na pastwę pozy porzucona,
na fałszywe świadectwo.

Fotografia zatrzymuje ruch i unieważnia proces przemijania, choć poetka ma świadomość, że jest też fałszowaniem rzeczywistości. Pojawiający się w drugim 
utworze antroponim tym bardziej to podkreśla, gdyż odsyła do Isadory Duncan i, jak sądzę, do okoliczności jej śmierci (zginęła uduszona podczas jazdy sportowym kabrioletem, gdy w koła pędzącego samochodu wkręcił się jej szal). Tylko wówczas tancerka zastyga w określonej pozie, jej naturalnym stanem jest ruch („Jeden krok z wiecznej sztuki w sztuczną wieczność”).

Ruch, rozumiany metaforycznie, może dotyczyć nie tylko człowieka i pokonywanej przez niego przestrzeni, ale i otaczającej go kultury i reprezentujących ją tekstów. W tym aspekcie nazwa własna stanowi istotny, choć postrzegany subiektywnie, składnik kontekstu kultury (por. Czopek-Kopciuch, 2010; Rejter, 2019). Są to niekiedy konteksty, które Szymborska próbuje unowocześnić lub zrekonstruować, jak w wierszu „Chwila w Troi”:

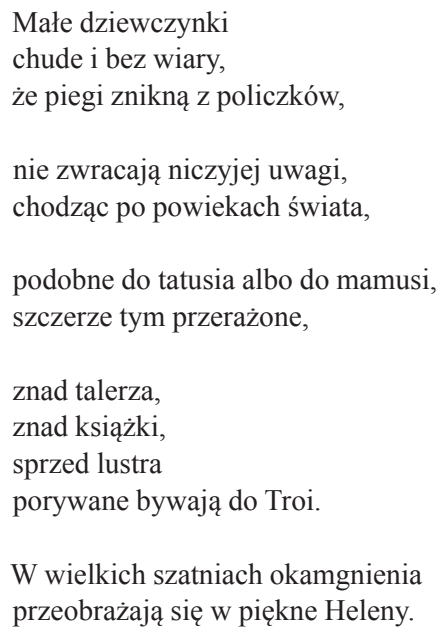

W poezji Szymborskiej stykamy się z pewną onimiczną ambiwalencją — z jednej strony — co podkreślają wielokrotnie jej komentatorzy (np. S. Balbus) — jest to liryka silnie osadzona w określonych, czytelnych dla Europejczyka odniesieniach kulturowych, z drugiej autorka „obmyśla świat”, konstruuje go na nowo, nadając rangę zdarzeniom, osobom, przedmiotom pozornie zwyczajnym, tworząc niespodziewanie wielowymiarowe sensy („Obmyślam świat, wydanie drugie, / wydanie drugie, poprawione").

Ma to swoje ontologiczne i epistemologiczne konsekwencje, gdyż w przestrzeni tej poezji wszystko jest równie ważne i wszystko warte jest opisania. W związku z tym następuje niemal automatyczne unieważnienie tego, co uznane za istotne przez autorytety - jak w wierszach „Dom wielkiego człowieka” lub „Pietà”, bohaterów, których nie dała nam poetka poznać z imienia i nazwiska, w przeciwieństwie do Baczyńskiego, który pojawia się w poetyckiej wizji 
świata możliwego („W biały dzien"). Obserwując świat, poetka notuje zarówno Napoleona („Listy umarłych”) czy Dickensa i Dostojewskiego („Możliwości”), jak i Jabłońska („,W przytułku”) czy babcię z Zabierzowa („Rozpoczęta opowieść”).

Wgląd w liryki Szymborskiej pozwala więc dostrzec, że nazwy własne oraz ich ekwiwalenty są tam bardzo często traktowane jak tekst pozbawiony jednostkowej denotacji. Jest to związane z realizowaną przez nią poetyką, którą charakteryzują „zwyczajność językowa” i ,powszechne i wytarte słowa”:

[...] cechą języka poetyckiego Szymborskiej są antynomie, paradoksy, oksymorony, wieloznaczność wyrażeń, kalambury, [...] znaczące milczenia i wiele mówiące przemilczenia. [...] są to wiersze równocześnie bardzo proste i bardzo skomplikowane, komunikatywne i głęboko niejednoznaczne (Balbus, 1996, s. 40-41).

Anna Pajdzińska wskazywała, że warstwa onimiczna utworów poetki odsyłająca do przestrzeni związanych z kulturą jest sygnałem erudycyjności tych utworów, a także wymagań stawianych czytelnikowi. Stanisław Balbus natomiast przekonuje, że sztuka (a więc i — dopowiedzmy — sygnalizujące ją onimiczne odniesienia) jest pretekstem do mówienia o jej fałszującej roli. W tym kontekście działania artystyczne, reprodukując rzeczywistość, tworzą świat wyidealizowany, konwencjonalny, zuniformizowany — słowem: utopię (Balbus, 1996, s. 50). Szymborska ma tego świadomość, stąd jej uważne przyglądanie się światu, notowanie najdrobniejszych szczegółów obserwowanych „,na marginesach” / „na peryferiach" wielkich spraw. Notacje te mają jednak swoje, także lingwistyczne, ograniczenia. Wtedy z pomocą przychodzą językowe kalki, stereotypowe konotacje, utarte zwroty, które Noblistka modyfikuje, przekształca, zamienia, dając im nowe życie. „Nie miej mi za złe, mowo, że pożyczam patetycznych słów, / a potem trudu dokładam, żeby wydały się lekkie” — prosi poetka („Pod jedną gwiazdką"). Stosowane przez nią zabiegi wzbogacają słownik o nowatorskie, także quasi-onimiczne zestawienia m.in.: Człowiek przez wysokie C („Koloratura”), woda babel („Woda”) lub ciężkie norwidy, („Wieczór autorski”), ale też modyfikują wartość konotacyjną onimów, np. powołując Prometeusza w strażackim kasku („Pisane w hotelu”), Homera pracującego w biurze statystycznym („Spis

${ }^{5}$ Warto na marginesie tej nazwy zwrócić uwagę na stosowane w thumaczeniu tej poezji strategie translatorskie, o których, na przykładzie nazwy Zabierzów, w interesujący sposób pisze Leonard Neuger. Badacz konstatuje m.in.: ,Język ojczysty traktowany jest przez użytkowników jako język obsługujący cały świat. To prawda, ale ten «cały świat» musi się mieścić w tym danym nam języku. Nawet otwarcie na światowość jest tu lokalne, ponieważ jest ono zawsze perspektywiczne. Nasza światowość nie musi zawsze pokrywać się ze światowością innych języków. Nasza oczywistość nie jest oczywistością uniwersalną. Identycznie ma się rzecz z językiem oryginału. W ramach tego języka powstaje lokalny idiom poety. A idiom ten budowany jest na specyficznie lokalnej kulturze kraju" (Neuger, 2017, s. 432). 
ludności”) czy Tartar kataru („Koloratura”). Watro zauważyć, że przywołując autentyczne miana lub ideonimy, Szymborska bardzo często czyni z nich metonimiczne komponenty poetyckich porównań, np.:

Świat tylko taki. Tylko tak

żyć. I umierać tylko tyle.

A wszystko inne — jest jak Bach

chwilowo grany

na pile.

(„Obmyślam świat”)

lub:

We śnie

maluję jak Vermeer van Delft.

(„Pochwała snów”)

w pewien sposób przywracając te nazwy do życia, ale też oddając przenikające się rejestry kultury wysokiej i popularnej, np.:

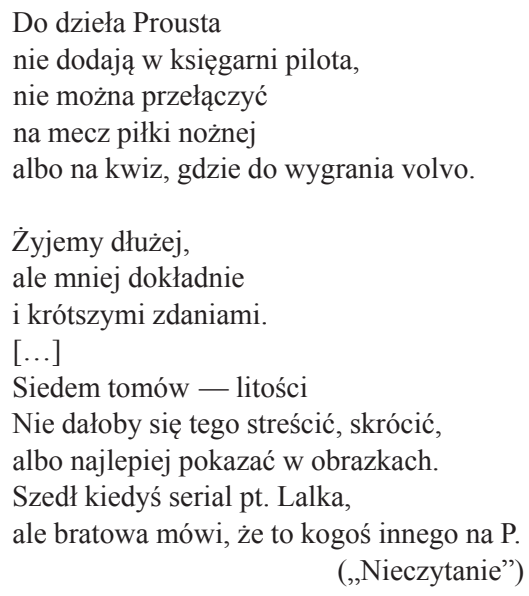

W przestrzeni tej poezji nazwa (zwłaszcza antroponim) przypomina etykietę, która została komuś/czemuś nadana. I taki „zastany” świat, nazwany wcześniej przez kogoś innego, ogląda i komentuje Noblistka. Nadanie nazwy przedmiotom wiąże się z ich indywidualizacją, posiadaniem, przynależnością, tymczasem w poezji Szymborskiej niemal wszystko jest czyjeś, pożyczone, z drugiej ręki, a nagromadzenie przedmiotów przypomina ich kolekcjonowanie. Stąd w tych utworach tak niewiele chrematonimów. Dotyczy to także ludzi i ich imion, przypadkowych, 
niepełnych, ,przymierzanych” do osoby niczym odzież, nadawanych ponownie, można tu przywołać ilustrującą to znakomicie koncepcję (kulturę) vintage:

Twarze.

Miliardy twarzy na powierzchni świata.

Podobno każda inna

od tych, co były i będą.

Ale Natura — bo kto ją tam wie -

może zmęczona bezustanną pracą

powtarza swoje dawniejsze pomysły

i nakłada nam twarze

kiedyś już noszone.

Może cię mija Archimedes w dżinsach, caryca Katarzyna w ciuchu z wyprzedaży, któryś faraon z teczką, w okularach.

(„Myśli nawiedzające mnie na ruchliwych ulicach”)

Aby podkreślić zastosowany koncept, poetka korzysta z toposów onimicznych (Sarnowska-Giefing, 2010), które jednak nie odsyłają do swych prymarnych znaczeń, zgodnie z koncepcją vintage Szymborska wykorzystuje ich kulturowe konotacje, ale nadaje im nowe życie. Można to łączyć ze wskazaną przez Edwarda Balcerzana taktyką ,sterowania pamięcią i wrażliwością odbiorcy” (Balcerzan, 2015, s. 101), ale też archetypowością wskazanej przez konwencjonalne miana sytuacji, która nabiera konkretnych znaczeń w zetknięciu z doświadczeniem (dyskretnie przez poetkę kierowanego) współczesnego czytelnika:

Nikt $\mathrm{w}$ rodzinie nie umarł z miłości.

Co tam było to było, ale nic dla mitu.

Romeowie gruźlicy? Julie dyfterytu?

Niektórzy wręcz dożyli zgrzybiałej starości.

Żadnej ofiary braku odpowiedzi

na list pokropiony łzami!

$$
\text { (,Album”) }
$$

oraz:

Przybywa nam dawności,

robi się w niej tłoczno,

rozpychają się w dziejach dzicy lokatorzy

[...]

Mijamy się na wieczność w domach towarowych

kupując nowy dzbanek.

Homer pracuje w biurze statystycznym.

Nikt nie wie, co robi w domu.

(„Spis ludności”) 
Poetycki antroponomastykon Szymborskiej, zwłaszcza nazwy autentyczne leksykalnie, odzwierciedla również obserwowaną w jej poezji powtarzalność historii i jej potencjalność oraz ,powierzchowność zakorzenienia człowieka w obiektywnych czasoprzestrzeniach" (Balbus, 1996, s. 41). Najwyrazistszym przykładem takiego zjawiska jest wiersz „ABC”, w którym poetka, podsuwając nam fałszywy trop autobiograficzny, wymienia inicjały „,ważnych” dla niej osób. Zarysowana sytuacja przypomina podsumowywanie życia i dokonywane przed śmiercią porządkowanie pamiątek, np. starych fotografii:

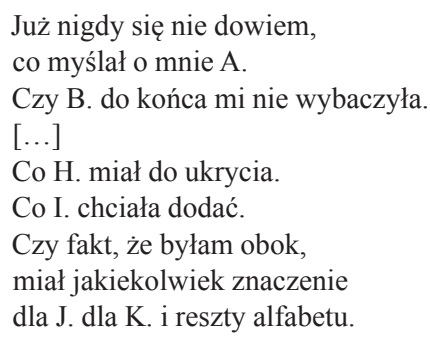

Nie dajmy się jednak zwieść poetce, która w innym utworze („Nieobecność”) dobrotliwie tłumaczy się czytelnikowi ze słabej pamięci do imion, twarzy i melodii, a „Trudne życie z pamięcią” jest tematem innego jej wiersza. Skierujmy za to uwagę na tekstową rolę inicjałów: nie mamy tu wszak typowej dla nich funkcji kamuflującej realną referencję czy aluzji do rzeczywistości. Co więcej, inicjały te, ułożone w porządku alfabetycznym, unieważniają trop związany z pracą pamięci. Nikt przecież nie przypomina sobie osób w określonym, zwłaszcza alfabetycznym, porządku ich imion (M. Graf, P. Graf, 2015, s. 180-181). To strategia przypominająca dawne leksykony, pozwalające poznać i uporządkować nieznaną rzeczywistość językową. Imię staje się więc, nie tylko w tym wierszu, synonimem jednostki słownikowej, leksemu i jego uogólnionego znaczenia. Przestaje być nazwą własną odsyłającą do określonego denotatu, a staje się tekstem wypełniającym się znaczeniem, wieloznacznym i i jednocześnie pozbawionym znaczenia (taki paradoks poezji Szymborskiej). Doskonale oddają to zabiegi, jakim poetka poddaje zaimki wskazujące i nieokreślone, np. w utworze „Przypowieść”, w którym mowa o nieznanym $t u$ (trudnym do ustalenia miejscu, w którym przebywa oczekujący pomocy rozbitek) oraz $T u$ - przestrzeni, w której żyjemy, zarówno osoby tekstowe, jak i czytelnik. Gdzie jest Tu? Jednocześnie wszędzie, jak i tutaj, w tym właśnie miejscu. Podobną wizję przestrzeni, wpisującej się we wskazane już wyżej światy możliwe, oddaje poetka w wierszu „Dworzec”: „Dworzec w mieście N. / dobrze zdał egzamin / z istnienia obiektywnego. [...] W raju utraconym / prawdopodobieństwa”. Czy dla interpretacji ważne jest, gdzie znajduje się miejscowość kryjąca 
się pod tą sygnaturą? Czy warto jej szukać na mapie? — poetka odradza takie rozwiązanie (także przez intertekstualne sygnały). „Lubię mapy, bo kłamią. / Bo nie dają dostępu napastliwej prawdzie. / Bo wielkodusznie, z poczciwym humorem / rozpościerają mi na stole świat / nie z tego świata". Mapa to symulakrum, w którym pozornie obiektywna wiedza o świecie łączy się z potocznymi o nim wyobrażeniami, toteż nawet miejsca zaznaczone przez kartografów implikują różne sensy uzależnione od wielu subiektywnych czynników. Warto jednak — szlakiem wytyczonym przez Szymborską — podążyć na wschód, do Japonii. A w tę podróż zabrać ze sobą tomik wierszy Kazimierza Wierzyńskiego. Oboje zainteresowało Kioto, któremu poświęcili kilka poetyckich strof. „Wszystkie Florencje / Powinny być podobne do Kioto” — tym zdaniem kończy poeta „Wiersz o Japonii”, idealizujący obraz dawnej stolicy kraju (Kiszka, 2016, s. 90-91). Wierzyński zwiedził ją w 1957 r., jednak miasto chyba go nie zainteresowało, w przeciwieństwie do czekającej na epistolarną relację żony poety ${ }^{6}$. Wskazuje na to wysłany z Kioto list, w którym nazwa miasta pojawia się tylko raz, w nagłówku. Można stąd wnioskować, że poetyckie zestawienie kultury wschodniej i zachodniej oraz symbolizujących je miast tylko na pozór upodrzędnia (m.in. przez zastosowanie synekdochy liczby) kulturę europejską. Tymczasem Szymborska, która niechętnie opuszczała Kraków i (najpewniej?) nie była w Japonii, poświęca Kioto sporo uwagi. Co jednak ciekawe, nie interesuje jej miasto jako miejsce na mapie, ale jako symbol, co wzmacnia antynomiczne zestawienie Kioto i Hiroszimy — miasta, które ocalało i miasta „skazanego na śmierć”. Poetycki kontrast jest tym silniejszy, że Kioto jest dziś uznawane za jedno z najpiękniejszych miast Japonii, co jest właśnie efektem tego, że uniknęło ono wojennych zniszczeń. Na przeciwległym biegunie poetka umieszcza jedno z miast unicestwionych przez bombę atomową:

Kioto ma szczęście,

szczęście i pałace,

[...]

Kioto jest miastem pięknym

aż do łez.

Prawdziwych łez

pewnego pana,

znawcy zabytków, miłośnika,

który w rozstrzygającej chwili

przy zielonym stole

${ }^{6}$ „Czytam jakąś starą histor[ię] literatury japońskiej, z której wynika raz jeszcze, że nazwa rzeczy właściwie nie istnieje, że istnie[ją] tylko światy, które dane słowo otwiera. Że wiśnia dla nas to owoc, a wiśnia dla Japończyka to drzewo i z tym połączona pamięć pory roku, kobiety [?], miłości i piękna przyrody. Ciekawa jestem, czy nic się nie mówi w Japonii po prostu, tylko zawsze przez sugestię raczej - tak jakby to wynikało z ich literatury" (z listu Haliny Wierzyńskiej; za: Dorosz, 2019, s. 162). 


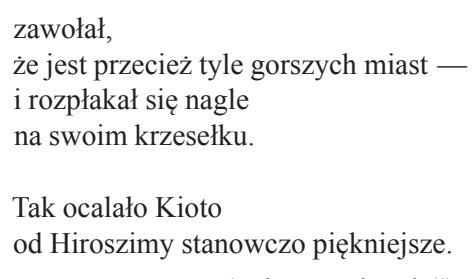

(,Pisane w hotelu”)

W wierszu słychać echa wielokrotnie przez poetkę wykorzystywanej koncepcji przypadku, próżno tu szukać uporządkowanej, harmonijnej rzeczywistości, w której nie ma miejsca na grę losu (Lewiński, 2001). Częściej poetka zastanawia się nad wpływem losu i konieczności, zarówno w skali mikro, jak i w aspekcie działania wszechświata. Czy to, co nam się przytrafia, ,zdarzyć się musiało”, a jeśli nie, to cóż innego „zdarzyć się mogło”? (,Wszelki wypadek”). I choć wybór, które z miast zostanie zniesione z powierzchni ziemi wydaje się wynikiem kontrolowanych działań, w wierszu jawi się jako nagła, by nie rzec: przypadkowa, decyzja, której towarzyszą silne emocje. Wrażenie to wzmacnia obraz zielonego stołu, który przywodzi na myśl stół bilardowy lub stolik do gry w pokera. Jak to możliwe? Dlaczego tak się stało? Kto podjął taką decyzję? — oto zagadka, którą stawia przed czytelnikiem Szymborska. Charakterystyczna dla tej poezji koncepcja czasu (,Ale to dawne dzieje. / Nie mogę wiecznie myśleć tylko o tym”) wpływa na stopniowe osłabienie symbolicznych, przypisanych denotatowi konotacji, stąd nawet Hiroszima, choć już w innym wierszu, ostatecznie podnosi się ze zniszczeń:

\author{
Tyle ciągle się dzieje, \\ że musi dziać się wszędzie. \\ Gdzie kamień na kamieniu, \\ tam wózek z lodami \\ oblężony przez dzieci. \\ Gdzie Hiroszima \\ tam znów Hiroszima \\ i wyrób wielu rzeczy \\ do codziennego użytku. \\ (,Rzeczywistość wymaga”)
}

„Nie starczy ust do wymówienia przelotnych imion twoich, wodo" — w przywołanym w tytule fragmencie wiersza Szymborskiej („Woda”), niczym w soczewce, skupiają się istotne konteksty związane z obecnością w poezji Noblistki nazw własnych. Woda płynie, jest zmienna, toteż można ją nazwać różnymi, jedynie tymczasowymi imionami. Nazwać w różnych językach, odmiennych czasoprzestrzeniach (lokalnych, globalnych, codziennych, kulturowych itp.), co spowoduje, że nadana nazwa nigdy nie będzie oddawała aktualnego stanu rzeczy. I choć 
w wierszu pojawiają się hydronimy, odsyłające zarówno do mapy, jak i przestrzeni mitu (np. Ganges), to wers: ,Pacyfik potulnie wpływa do Rudawy / tej samej, co fruwała chmurką nad Paryżem" udowadnia, że nawet nazwany obiekt nie daje się łatwo zinterpretować jako miejsce geograficzne, umieszczone na mapie. Przelotność imion wiąże się też z chwilową bezimiennością, jak w przypadku jeziora, które nie doczekało się nazwy. Według Michała Rogoża:

Określone „miejsce na ziemi” stanowi z jednej strony swoiste rozszerzenie kontekstu wypowiedzi literackiej, z drugiej zaś jest elementem identyfikacyjnym pozwalającym ustalić związki autora $\mathrm{z}$ określoną przestrzenią geograficzną, jego zakorzenienie w kulturze lokalnej oraz doświadczenie wpływające na obrazowanie poetyckie i konkretny sposób przedstawiania świata (Rogoż, 2013, s. 347-348).

Dla Szymborskiej takim miejscem jest niewątpliwie Kraków. To on, za pośrednictwem nazwy rzeki wpływającej do Wisły na wysokości krakowskiego klasztoru Norbertanek, zostaje przez poetkę naznaczony jako centralny punkt jej prywatnej czasoprzestrzeni, lokalny genius loci. Żeby go jednak wyznaczyć, należy unieruchomić czas i przestrzeń. Tak jak poetycka Troja jest miastem palimpsestem, w którym na odkopane przez archeologów ruiny nakładają się kolejne, powstające na tym miejscu osady, tak woda ma wiele przenikających się, dynamicznych form istnienia. To więc nie tylko rzeka płynąca w Krakowie lub przepływająca przez mityczne, zatopione miasto Ys, Morze Kaspijskie czy Pacyfik, ale też niszczycielski żywioł czy szklanka płynu podana umierającemu — tekst natury i tekst kultury. Można jej więc nadać jedno uniwersalizujące imię? Szymborska, patrząc z dystansu, ,ze skraju mapy”, przekonuje, że nie. Niemożliwe jest bowiem opisanie ,świata ze wszystkich stron świata” („Urodziny”).

\section{ŹRÓDŁO}

Szymborska, W. (2012). Wiersze wybrane. Wyd. nowe, uzupełnione, Poznań: Wydawnictwo a5.

\section{LITERATURA}

Balbus, S. (1996). Świat ze wszystkich stron świata. O Wisławie Szymborskiej [The World from all over the World. About Wisława Szymborska]. Kraków: Wydawnictwo Literackie.

Balcerzan, E. (2015). Wyklejanki — felietony — wiersze [Cut-offs — columns — poems]. W: J. Grądziel-Wójcik i K. Skibski (red.), Niepojęty przypadek. O poezji Wisławy Szymborskiej [Unthinkable Coincidence. On Wisława Szymborska's Poetry] (s. 93-116). Kraków: Pasaże.

Borkowska, G. (1991). Szymborska eks-centryczna [Szymborska ex-centric]. Teksty Drugie, $4(10), 45-58$. 
Czopek-Kopciuch, B. (2010). Funkcje nazw własnych w poezji Zbigniewa Herberta (na przykładzie tomiku „Pan Cogito”) [Functions of proper names in the poetry of Zbigniew Herbert (on the example of "Pan Cogito")]. W: R. Łobodzińska (red.), Nazwy własne a społeczeństwo [Proper Names and Society] (t. I, s. 445-452). Łask: Leksem.

Dorosz, B. (2019). „Anioł chopinowski” i „nienapisany wiersz”. O korespondencji Haliny i Kazimierza Wierzyńskich (tuzin listów i garść uwag) [“Chopin’s Angel” and "an unwritten poem". About the correspondence of Halina and Kazimierz Wierzyński (a dozen letters and a handful of comments)]. Sztuka Edycji, 2, 153-174.

Flusser, V. (2015). Ku filozofii fotografii [Towards the Philosophy of Photography]. Przel. J. Maniecki. Warszawa: Aletheia.

Graf, M. i Graf, P. (2015). „Nie, nie, to na nic” — Szymborskiej poszukiwanie słowa [“No, no, it's pointless" - Szymborska in search for words]. W: J. Grądziel-Wójcik, K. Skibski (red.), Niepojęty przypadek. O poezji Wisławy Szymborskiej [Unthinkable Coincidence. On Wisława Szymborska's Poetry] (s. 173-191). Kraków: Pasaże.

Graf, M. i Graf, P. (2018). Nazwa w butonierce — wokół onimii tekstu poetyckiego (na przykładzie poezji Brunona Jasieńskiego) [A name in a buttonhole - onymy in poetic texts (based on the example of Bruno Jasieński's poetry)]. Onomastica, 62, 15-31.

Gralewicz-Wolny, I. (2014). Poetka i Świat. Studia i szkice o twórczości Wisławy Szymborskiej [The Poetess and the World. Studies and Drafts on Works by Wisława Szymborska]. Katowice: Wydawnictwo Naukowe UŚ.

Jezierska, J. (2018). Polityczna, moralna czy kryminalna? Rozważania o winie na podstawie teorii Karla Jaspersa [Political, moral or criminal? Reflections on guilt based on Karl Jaspers' theory]. Archiwum Filozofii Prawa i Filozofii Społecznej, 2, 90-102.

Karwowska, B. (2004). Kobieca perspektywa w poezji Szymborskiej — próba postfeministycznej refleksji [Women's perspective in Szymborska's poetry — an attempt at a postfeminist perspective]. Teksty Drugie, 3, 79-90.

Kiszka, B. (2016). Od „Hollywood” po mistyczne „Koluszki” - nazwy własne w poezji Kazimierza Wierzyńskiego [From "Hollywood" to the mystical "Koluszki" - proper names in the poetry of Kazimierz Wierzyński]. W: J. Przyklenk i W. Wilczek (red.), Bogactwo polszczyzny w świetle jej historii [The Richness of the Polish Language in the Light of Its History] (t. 6, s. 83-99). Katowice: Wydawnictwo Naukowe.

Kolasa, D. (2010). Sytuacje możliwe a sytuacje graniczne w filozofii Jaspersa [Possible situations and limit situations in Karl Jaspers' philosophy]. Studia z Historii Filozofii, 1 (1), 135-145.

Lewiński, J. (2001). Wisławy Szymborskiej przypadki [Wisława Szymborska’s haphazards]. Acta Universitatis Lodziensis. Folia Litteraria Polonica, 2, 83-103.

Neuger, L. (2010). Babcia z Zabierzowa. Przekład z lokalnego na lokalny [Grandma in Zabierzów. Translation from local to local]. Teksty Drugie, 1, 432-439.

Pajdzińska, A. (2010). Antroponimy w poezji Wisławy Szymborskiej [Anthroponyms in Wisława Szymborska's poetry]. W: H. Pelcowa (red.), W'́wiecie nazw. Ksiegga jubileuszowa dedykowana Profesorowi Czestawowi Kosylowi [In the World of Names. Festschrift Dedicated to Professor Czesław Kosyl] (s. 301-312). Lublin: Wydawnictwo UMCS.

Rejter, A. (2019). „Byłaś już w Paryżach stu...” Aksjologiczny aspekt nazw własnych w twórczości poetyckiej Agnieszki Osieckiej [“You've already been to a hundred Parises ..." Axiological aspect of proper names in Agnieszka Osiecka's poetry]. W: Tenże, Nazwy własne w kon/tekstach kultury [Proper Names in Con/texts of Culture] (s. 223-242). Katowice: Wydawnictwo Naukowe UŚ.

Rogoż, M. (2013). „Tam, gdzie Pacyfik potulnie wpływa do Rudawy”. Od miejsca geograficznego do antropologicznego kontekstu w twórczości Wisławy Szymborskiej ["Where the Pacific Ocean meekly flows into the Rudawa River". From a geographic place to an anthropological context in the works of Wisława Szymborska]. Ruch Literacki, 54(3), 347-363. 
Sarnowska-Giefing, I. (2010). Toposy i tematy imienne w perspektywie onomastyki literackiej [Toposes and naming subjects in the perspective of literary onomastics]. W: H. Pelcowa (red.), $W$ świecie nazw. Księga jubileuszowa dedykowana Profesorowi Czestawowi Kosylowi [In the World of Names. Festschrift Dedicated to Professor Czesław Kosyl] (s. 345-355). Lublin: Wydawnictwo UMCS.

Sztobryn-Bochomulska, J. (2016). Koncepcja egzystencji Karla Jaspersa jako przyczynek do refleksji nad codziennością wychowania [The concept of existence by Karl Jaspers as a contribution to reflection on the everyday reality of education]. Nauki o Wychowaniu. Studia Interdyscyplinarne, 1(2), 147-155.

Żelazny, M. (2010). Jaspersowska wizja psychoterapii [Jasper's view on psychotherapy]. Studia $z$ Historii Filozofii, 1, 119-134.

\section{SUMMARY}

\section{“THERE ARE NOT ENOUGH MOUTHS TO UTTER ALL YOUR FLEETING NAMES, O WATER" - PROPER NAMES IN WISLAWA SZYMBORSKA'S WORKS}

There are many studies concerning Wisława Szymborska's works, especially in the field of literary studies. Researchers (including S. Balbus, E. Balcerzan, A. Legeżyńska) have discussed in detail the features and the most important themes of her poetry. They also paid attention to stylistic devices and language games used by the poet. However, they were little interested in the onymic layer of her poems. Meanwhile, Szymborska's poetry is a rich source of proper names, which appear independently or constitute elements of metaphors and comparisons. Among these onyms, there are both anthroponyms and place names, hydronyms and ideonyms. The poet's oeuvre also includes works devoid of proper names, which is also an important signal of textual functions (e.g. concealment, evanescence, uncertainty). The conducted analyses (e.g. of the poem "Portrait of a woman") show how the analysis of proper names enriches the interpretative conclusions.

Keywords: literary onomastics, proper names in poetry, Wisława Szymborska 